the Commission, which is the body responsible, wishes to place no check on scientific excavation, whether by organisations or individuals properly accredited; but it aims at the ' amateur' who seeks to exploit a site for his personal and pecuniary gain. In this praiseworthy object, French archæologists will have the moral support of their colleagues, whatever their nationality, and also in what is clearly their secondary object, namely, to secure the control of the finds-thus averting such a catastrophe as occurred when the skeletal remains found in the caves of Le Moustier and Combe Capelle were lost to France.

Restoration of Roman Bridge, Littleborough, Lancs

ADVANTage has been taken of the unemployment problem at littleborough, Lancs, to invite the cooperation of voluntary workers among the unemployed on the 'dole' in the repair of the Roman road over Blackstone Edge. A part of the work contemplated has now been completed by the repair of the Roman bridge at the junction of Black Castle Clough and Rag Sapling Clough, which carries the road over Black Castle Clough. Some time ago, Mr. J. H. Price of Rochdale directed the attention of the Rochdale Literary and Seientific Society, and through it, of the Society for the Protection of Ancient Monu. ments, to the fact that the bridge was in danger of being swept away. Mr. Price's examination of the bridge had revealed the fact, which had been completely forgotten in the course of time, that originally it consisted of two culverts, one of which had collapsed and had become completely overgrown with grass. The original length of $25 \mathrm{ft}$. had thereby been reduced to $12 \mathrm{ft}$. This eulvert has now been restored and the bridge repaired, under Mr. Price's supervision, with the assistance of local firms who volunteered transport, material, etc. The work was carried out with the approval of H.M. Office of Works. Both Roman road and bridge are scheduled as ancient monuments. It is hoped to carry out repairs on part of the road in due course by the same method.

\section{Salamanders and the Pollution of Drinking Water}

A curious and unsuspected source of pollution of drinking-water has just been discovered in Cattaraugus County in western New York State (William G. Hassler in Natural History, New York, May-June, 1932, p. 303). Certain spring supplies of water continued to give unsatisfactory laboratory tests even after drastic steps had been taken to protect the springs from outside pollution. Further examination revealed that salamanders, large newt-like amphibians, belonging to four different species, occasionally occurred in the springs, and though a first examination showed that only a small percentage contained the colon bacillus, the investigation was continued. Nearly two hundred purple salamanders (Gyrinophilus porphyriticus) were marked with identification discs, and subsequent collecting proved that sometimes individuals wandered as much as sixty-five feet from the stream, apparently in search of food. One was observed eating fly larvæ which were living on mammalian refuse, and this settled the question of how colon bacilli entered the food canals of the salamanders. A second surprise was sprung upon the investigators when they studied more closely the numbers of salamanders in the springs themselves. Purple salamanders were not thought to be particularly common, but repeated nightly visits resulted in a catch of 144 in one spring, which contained about fifty more uncaught. Yet there were occasions when not one of these salamanders could be found, although all the catch was marked and returned to its spring. Laboratory experiments gave some idea of the extent to which contamination might take place. Over a period of 122 days, one salamander excreted a sufficient number of colon bacilli to contaminate 237 gallons of water heavily enough to be considered dangerous on every test. It is believed that the creatures act as reservoirs or incubators, and once infected with colon bacilli, continue to excrete them so long as there is food in the stomach or intestines to supply nourishment to the bacteria.

\section{Fishing with Captive Sucking Fish}

MoRe than four centuries ago, Columbus observed the strange custom of catching fish and turtles by meuns of captive sucking fish in the "Jardinellas de Ia Reina". The general impression has been that these islands were near Haiti and Jamaica, but C. Ralph de Sola points out that a more likely place is the archipelago in the Bight of Manzanillo on the south coast of Cuba (Copeia, p. 45, 1932). If this be so, Gudger is wrong in concluding that the original site of the discovery of Columbus " no longer witnesses the exploits of the fisherman fish ", for the Siboneyes of southern Cuba, a people of Carib extraction, still practice remora-fishing to a considerable extent. De Sola describes a fishing trip from Matanzas, Cuba. To the under-planks of the boat two sucking-fishes were firmly attached by their discs, and when a turtle was sighted basking on the surface, the fishes were detached and cast as far as possible towards the turtle. The sucking-fishes were themselves held captive by a long thin rope of majuga bark, attached in front of the tail, and so soon as they had fixed upon their quarry, the lines were drawn in and the captured hawk's-bill turtle taken aboard. Throughout the proceedings the lines had to be kept taut, and the author states that owing to the arrangement of the lamellæ of the sucker, it is impossible for the remora to relax its hold when tension is placed on its horizontal axis. It is curious that so peculiar a mode of fishing should be found in many distant parts of the world, but Gudger's records from various localities in Africa, Asia, Australia, South America, and the West Indies show that it is almost cosmopolitan in tropical seas.

\section{Eradication of Slugsand Snails}

IN a communication to NATURE on the eradication of slugs, which was the subject of a note in these columns on July 16 (p. 90), Mr. Walker Van Riper, 771 South High Street, Denver, Colorado, contributes another method of control based on his own experience. A generous distribution of a solution of ammonium sulphide ( 1 part in 30 parts of water) killed nearly all the slugs present in his garden in a single (Continued on p. 361.)

$$
\text { No. 3279, Vor. 130] }
$$

